\title{
Mixing state of oxalic acid containing particles in the rural area of Pearl River Delta, China: implications for the formation mechanism of oxalic acid
}

\section{Chunlei Cheng et al.}

Correspondence to: Mei Li (limei2007@163.com) and Zhen Zhou (zhouzhen@gig.ac.cn)

The copyright of individual parts of the supplement might differ from the CC BY 3.0 License. 


\section{Supplementary materials}

\section{Table list:}

Table S1. The SPAMS markers used to search for major groups of oxalic acid particles in this work.

\section{Figure caption:}

Figure S1. The topography of Heshan sampling site $(22.73 \mathrm{~N}, 112.93 \mathrm{E})$ and its surrounding areas.

Figure S2. The positive and negative mass spectra of oxalic acid measured by SPAMS through standard oxalic acid solution $\left(400 \mu \mathrm{g} \bullet \mathrm{ml}^{-1}\right)$.

Figure S3. The temporal variation of in-situ $\mathrm{pH}\left(\mathrm{pH}_{i s}\right)$ of ambient $\mathrm{PM}_{2.5}$ particles during sampling period in summer.

Figure S4. The clustered $48 \mathrm{hr}$ back trajectories of air masses arriving in Heshan during the sampling period: (a) summer (from July 18 to August 1, 2014), (b) winter (from January 27 to February 8, 2015).

Figure S5. The diurnal variations of in-situ $\mathrm{pH}\left(\mathrm{pH}_{i s}\right), \mathrm{RH}$, nitrate, sulfate, ammonium and the aqueous phase concentration of $\mathrm{H}^{+}\left(\mathrm{mol} \mathrm{L}^{-1}\right)$ in aerosols from July 28 to August 1 in 2014.

Figure S6. The diurnal variations of temperature (T), RH, wind speed (WS), oxalic acid particles, total EC particles, the EC type oxalic acid-containing particles and ambient $\mathrm{NO}_{2}$ concentrations from July 28 to August 1 in 2014.

Figure S7. Temporal variation of organosulfate $(\mathrm{m} / \mathrm{z}=-155)$ containing particles in total particles and in oxalic acid particles in Heshan, China. 
Table S1. The SPAMS markers used to search for major groups of oxalic acid particles in this work.

\begin{tabular}{|c|c|c|c|c|c|}
\hline Species & $\mathrm{m} / \mathrm{z}$ & Marker Ion & Area & $\begin{array}{l}\text { Relative } \\
\text { Area }\end{array}$ & Function \\
\hline \multirow[t]{10}{*}{ Elemental Carbon } & $12 \pm 0.5$ & {$[\mathrm{C}]^{+}$} & 50 & 0.005 & or \\
\hline & $24 \pm 0.5$ & {$\left[\mathrm{C}_{2}\right]^{+}$} & 50 & 0.005 & or \\
\hline & $36 \pm 0.5$ & {$\left[\mathrm{C}_{3}\right]^{+}$} & 50 & 0.005 & or \\
\hline & $48 \pm 0.5$ & {$\left[\mathrm{C}_{4}\right]^{+}$} & 50 & 0.005 & or \\
\hline & $60 \pm 0.5$ & {$\left[\mathrm{C}_{5}\right]^{+}$} & 50 & 0.005 & or \\
\hline & -12 & {$[\mathrm{C}]^{-}$} & 50 & 0.005 & or \\
\hline & -24 & {$\left[\mathrm{C}_{2}\right]^{-}$} & 50 & 0.005 & or \\
\hline & -36 & {$\left[\mathrm{C}_{3}\right]^{-}$} & 50 & 0.005 & or \\
\hline & -48 & {$\left[\mathrm{C}_{4}\right]^{-}$} & 50 & 0.005 & or \\
\hline & -60 & {$\left[\mathrm{C}_{5}\right]^{-}$} & 50 & 0.005 & or \\
\hline \multirow[t]{2}{*}{ Organic Carbon } & 27 & {$\left[\mathrm{C}_{2} \mathrm{H}_{3}\right]^{+}$} & 50 & 0.005 & or \\
\hline & 43 & {$\left[\mathrm{C}_{2} \mathrm{H}_{3} \mathrm{O}\right]^{+}$} & 50 & 0.005 & or \\
\hline \multirow[t]{5}{*}{ Elemental Carbon and Organic Carbon } & 12 & {$[\mathrm{C}]^{+}$} & 50 & 0.005 & or \\
\hline & 24 & {$\left[\mathrm{C}_{2}\right]^{+}$} & 50 & 0.005 & or \\
\hline & 36 & {$\left[\mathrm{C}_{3}\right]^{+}$} & 50 & 0.005 & or \\
\hline & 37 & {$\left[\mathrm{C}_{3} \mathrm{H}\right]^{+}$} & 50 & 0.005 & or \\
\hline & 43 & {$\left[\mathrm{C}_{2} \mathrm{H}_{3} \mathrm{O}\right]^{+}$} & 50 & 0.005 & or \\
\hline \multirow[t]{6}{*}{ Biomass Burning } & 39 & {$[\mathrm{~K}]^{+}$} & 1500 & & and \\
\hline & 113,115 & {$\left[\mathrm{~K}_{2} \mathrm{Cl}\right]^{+}$} & 50 & 0.005 & or \\
\hline & 213 & {$\left[\mathrm{~K}_{3} \mathrm{SO}_{4}\right]^{+}$} & 50 & 0.005 & or \\
\hline & -26 & {$[\mathrm{CN}]^{-}$} & 50 & 0.005 & or \\
\hline & -59 & {$\left[\mathrm{C}_{2} \mathrm{H}_{3} \mathrm{O}_{2}\right]^{-}$} & 50 & 0.005 & or \\
\hline & -73 & {$\left[\mathrm{C}_{3} \mathrm{H}_{3} \mathrm{O}_{2}\right]^{-}$} & 50 & 0.005 & or \\
\hline \multirow[t]{4}{*}{ Sec } & 18 & {$\left[\mathrm{NH}_{4}\right]^{+}$} & 50 & 0.005 & or \\
\hline & 39 & {$[\mathrm{~K}]^{+}$} & 1500 & & and \\
\hline & -62 & {$\left[\mathrm{NO}_{3}\right]^{-}$} & 100 & 0.05 & \\
\hline & -97 & {$\left[\mathrm{HSO}_{4}\right]^{-}$} & 100 & 0.05 & \\
\hline \multirow[t]{8}{*}{ Heavy Metal } & 206-208 & {$[\mathrm{Pb}]^{+}$} & 50 & 0.005 & or \\
\hline & 64,66 & {$[\mathrm{Zn}]^{+}$} & 50 & 0.005 & or \\
\hline & 63,65 & {$[\mathrm{Cu}]^{+}$} & 50 & 0.005 & or \\
\hline & 56 & {$[\mathrm{Fe}]^{+}$} & 50 & 0.005 & or \\
\hline & 55 & {$[\mathrm{Mn}]^{+}$} & 50 & 0.005 & or \\
\hline & 71 & {$[\mathrm{MnO}]^{+}$} & 50 & 0.005 & or \\
\hline & 51 & {$[\mathrm{~V}]^{+}$} & 50 & 0.005 & or \\
\hline & 67 & {$[\mathrm{VO}]^{+}$} & 50 & 0.005 & or \\
\hline \multirow[t]{4}{*}{ Dust } & 24 & {$[\mathrm{Mg}]^{+}$} & 1000 & & \\
\hline & 27 & {$[\mathrm{Al}]^{+}$} & 1500 & & \\
\hline & 40 & {$[\mathrm{Ca}]^{+}$} & 2500 & & \\
\hline & 56 & {$[\mathrm{CaO}]^{+} /[\mathrm{Fe}]^{+}$} & 100 & 0.05 & \\
\hline
\end{tabular}




\begin{tabular}{|l|l|l|l|l|l|}
\hline & -76 & {$\left[\mathrm{SiO}_{3}\right]^{-}$} & 500 & 0.05 & \\
\hline NaK & 23 & {$\left[\mathrm{Na}^{+}\right.$} & 100 & 0.05 & \\
\hline & 62 & {$\left[\mathrm{Na}_{2} \mathrm{O}\right]^{+}$} & 50 & 0.005 & or \\
\hline & 63 & {$\left[\mathrm{Na}_{2} \mathrm{OH}\right]^{+}$} & 50 & 0.005 & or \\
\hline & 81,83 & {$\left[\mathrm{Na}_{2} \mathrm{Cl}\right]^{+}$} & 50 & 0.005 & or \\
\hline Ammonium & $-35,-37$ & {$[\mathrm{Cl}]^{-}$} & 100 & 0.05 & \\
\hline Nitrate & 18 & {$\left[\mathrm{NH}_{4}\right]^{+}$} & 50 & 0.005 & \\
\hline & -46 & {$\left[\mathrm{NO}_{2}\right]^{-}$} & 100 & 0.05 & \\
\hline Sulfate & -62 & {$\left[\mathrm{NO}_{3}\right]^{-}$} & 100 & 0.05 & \\
\hline & -80 & {$\left[\mathrm{SO}_{3}\right]^{-}$} & 100 & 0.05 & \\
\hline & -97 & {$\left[\mathrm{HSO}_{4}\right]^{-}$} & 100 & 0.05 & \\
\hline
\end{tabular}




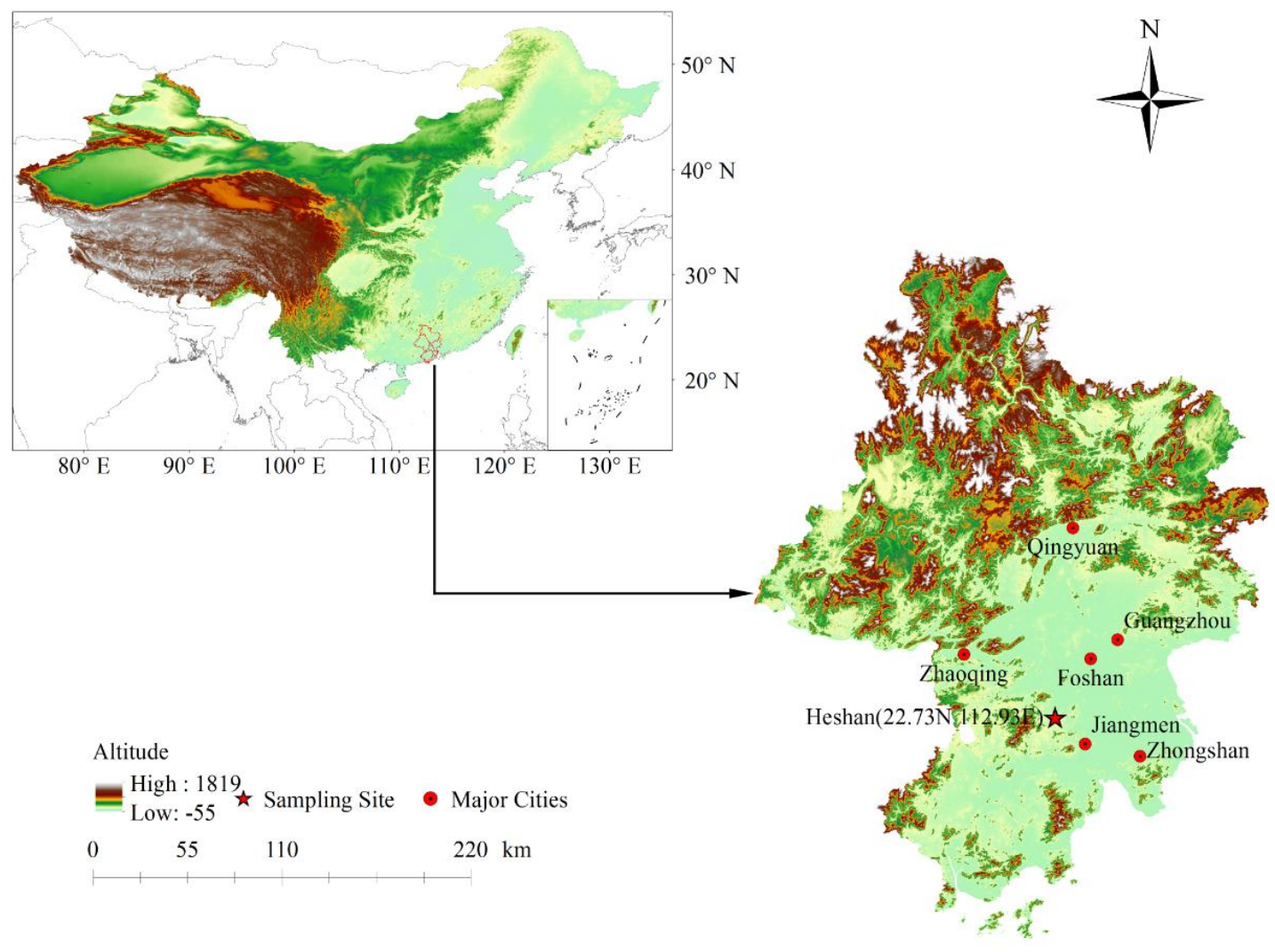

Figure S1. The topography of Heshan sampling site $(22.73 \mathrm{~N}, 112.93 \mathrm{E})$ and its surrounding areas. 


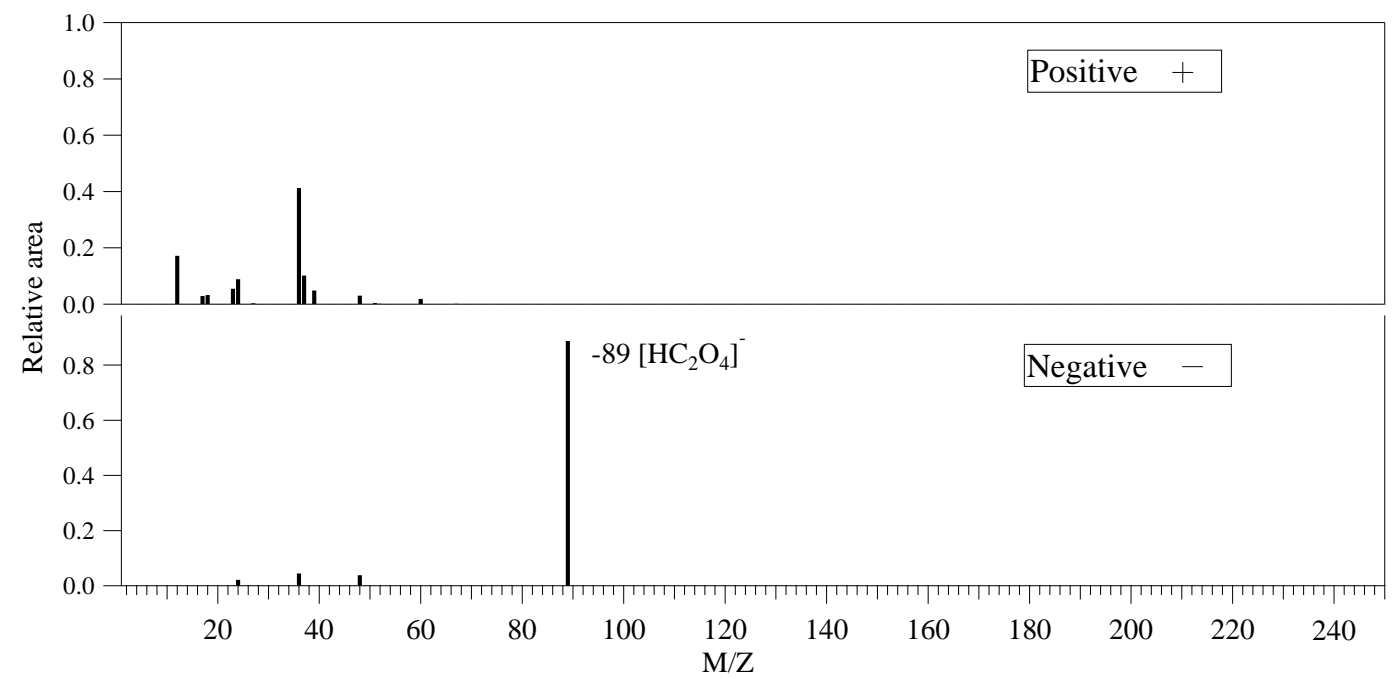

Figure $\mathrm{S} 2$. The positive and negative mass spectra of pure oxalic acid $\left(\mathrm{H}_{2} \mathrm{C}_{2} \mathrm{O}_{4}\right.$, purity: 99.99\%, Aladdin Industrial Corporation) measured by SPAMS through authentic oxalic acid solution $\left(200 \mu \mathrm{g} \bullet \mathrm{ml}^{-1}\right)$.

The relative area of each fragment refers to the abundance of each peak area in total signal of the mass spectra. The parent ion signal of oxalic acid at mass-to-charge $(\mathrm{m} / \mathrm{z})-89\left(\mathrm{HC}_{2} \mathrm{O}_{4}{ }^{-}\right)$is significant in the negative mass spectrum. Carbon clusters of $12[\mathrm{C}]^{+}, 24\left[\mathrm{C}_{2}\right]^{+}, 36\left[\mathrm{C}_{3}\right]^{+}$are observed in positive mass spectrum, and $23[\mathrm{Na}]^{+}$and $39[\mathrm{~K}]^{+}$also show peaks due to extremely high sensitivity of SPAMS to these elements which are present as trace impurities $(<0.01) . \mathrm{HC}_{2} \mathrm{O}_{4}{ }^{-}(\mathrm{m} / \mathrm{z}-89)$ is selected as the marker ion for oxalic acid containing particles. In this work, oxalic acid particles are identified if the peak area of $\mathrm{m} / \mathrm{z}-89$ was larger than $0.5 \%$ of the total signal in the mass spectrum. 


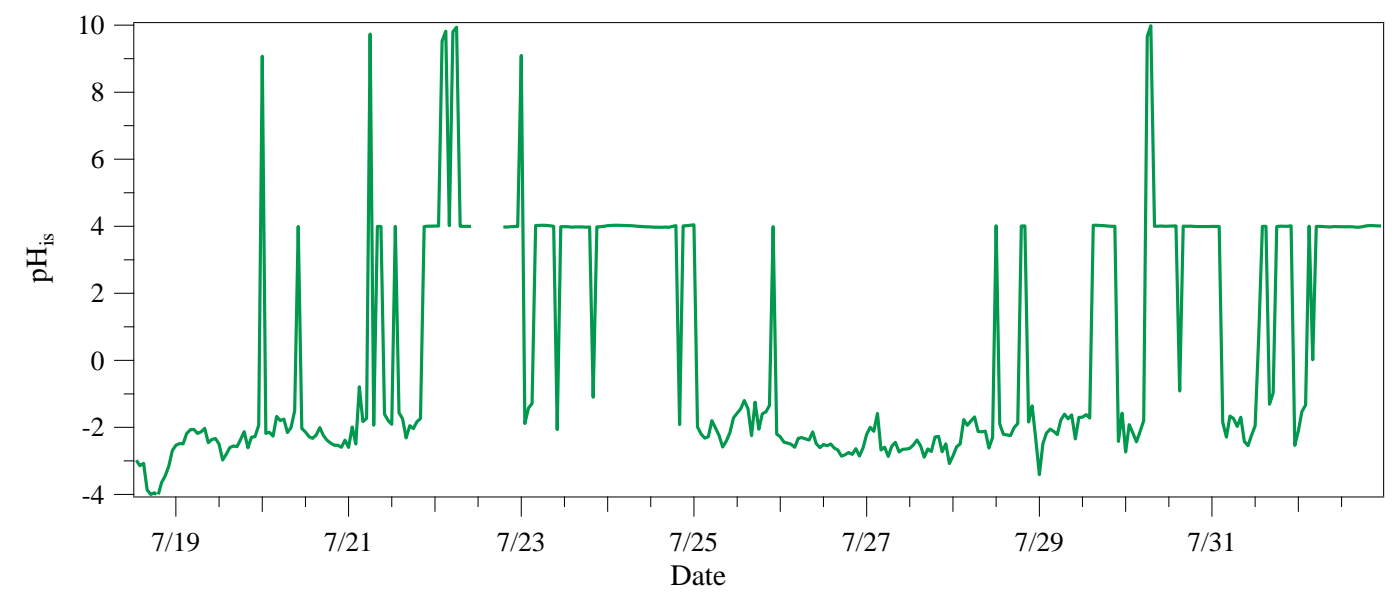

Figure S3. The temporal variation of in-situ $\mathrm{pH}\left(\mathrm{pH}_{i s}\right)$ of ambient $\mathrm{PM}_{2.5}$ particles during sampling period in summer.
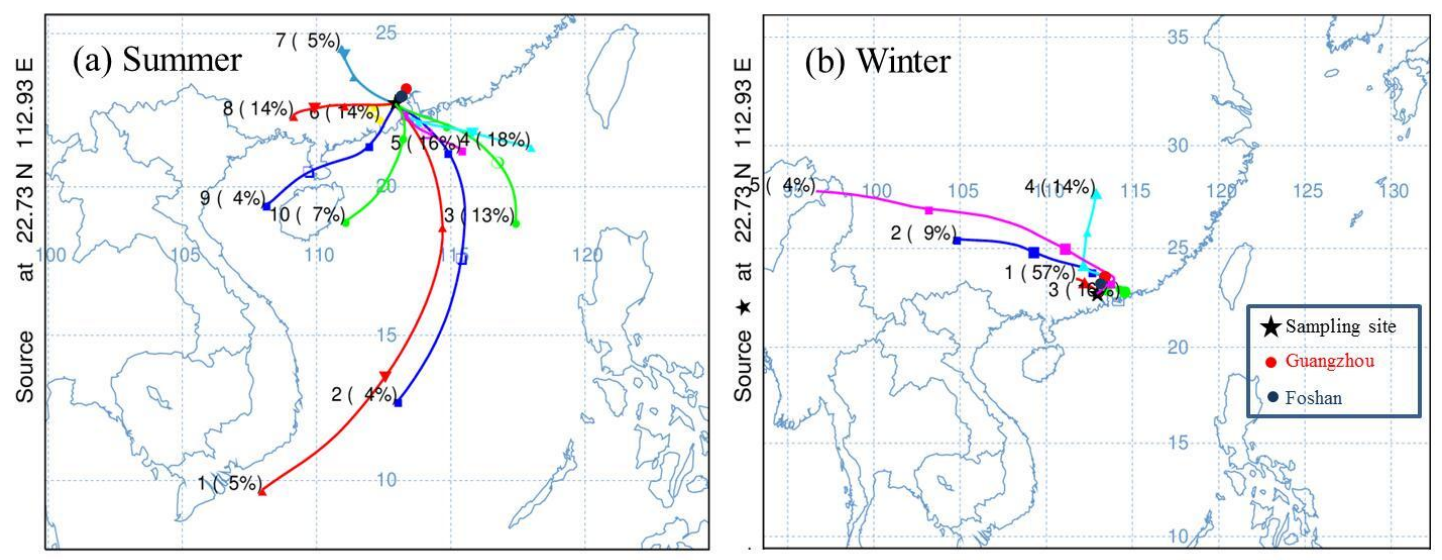

Figure S4. The clustered $48 \mathrm{hr}$ back trajectories of air masses arriving in Heshan during the sampling period: (a) summer (from July 18 to August 1, 2014), (b) winter (from January 27 to February 8, 2015). 


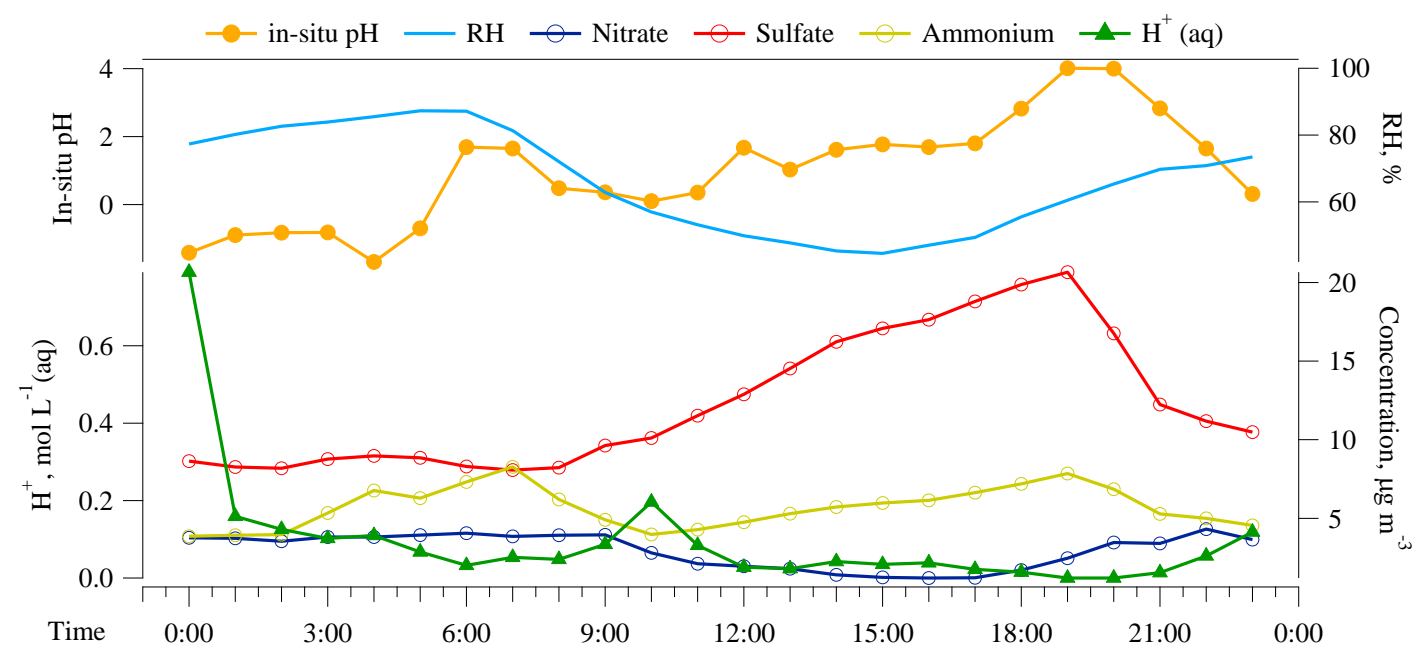

Figure S5. The diurnal variations of in-situ $\mathrm{pH}\left(\mathrm{pH}_{i s}\right), \mathrm{RH}$, nitrate, sulfate, ammonium and the aqueous phase concentration of $\mathrm{H}^{+}\left(\mathrm{mol} \mathrm{L}^{-1}\right)$ in aerosols from July 28 to August 1 in 2014.

The $p H_{i s}$ of ambient particles ranged from -1.42 to 4.01 , which indicate that fine particles in the sampling site are highly acidic. These values are within the range of previous studies that investigated $p H_{i s}$ through filter-based and real-time measurements in the PRD area (Xue et al., 2011;Pathak et al., 2004;Yao et al., 2006). Based on the calculation equation, the $p H_{i s}$ is determined by the concentration of $\mathrm{H}^{+}$ and liquid water content (LWC) in the aerosols. LWC is strongly dependent on the ambient RH and water-soluble inorganic salts like sulfate, nitrate and ammonium in the aerosols. The aqueous phase concentration of $\mathrm{H}^{+}$was lower from 12:00 to 21:00 compared to other time, which suggests a less acidity effect on the photochemical production of oxalic acid during this period. 


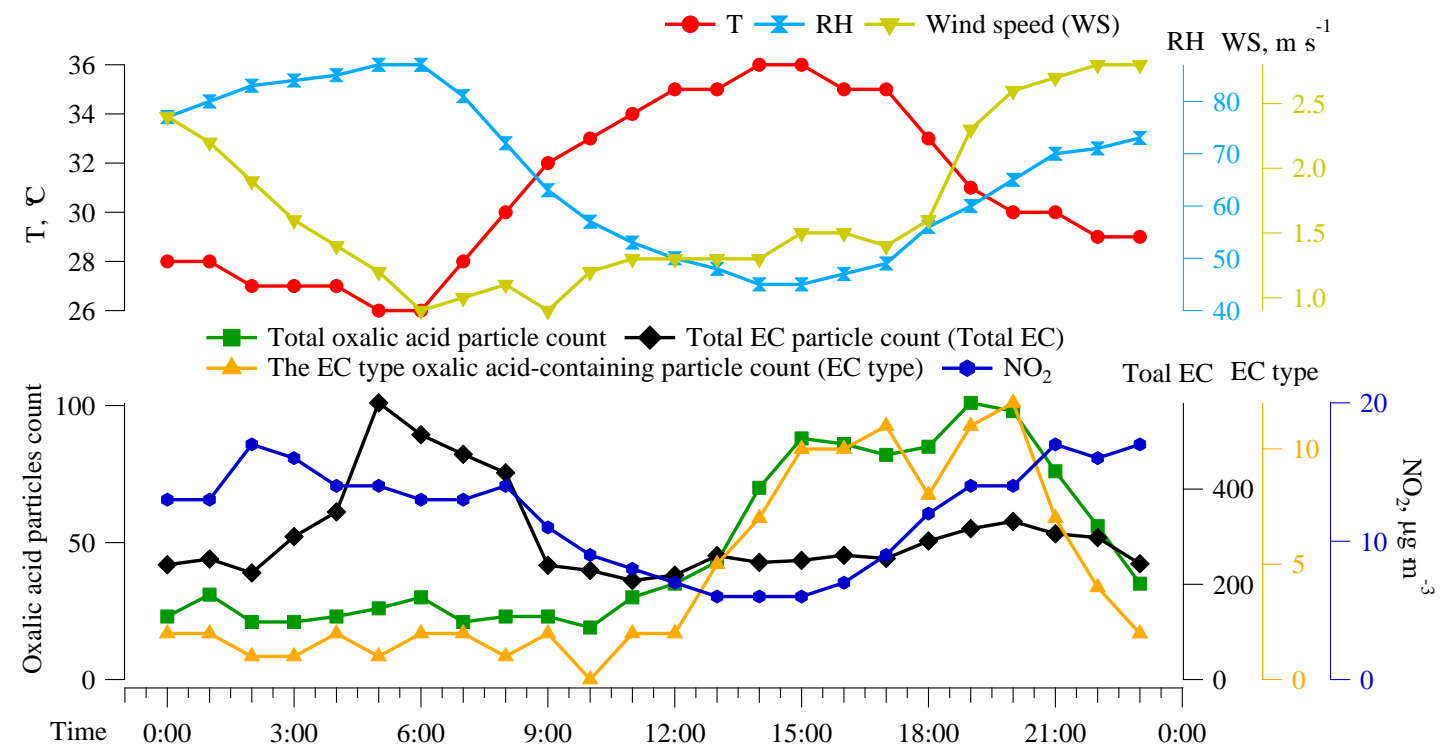

Figure S6. The diurnal variations of temperature (T), RH, wind speed (WS), oxalic acid particles, total EC particles, the EC type oxalic acid-containing particles and ambient $\mathrm{NO}_{2}$ concentrations from July 28 to August 1 in 2014. 


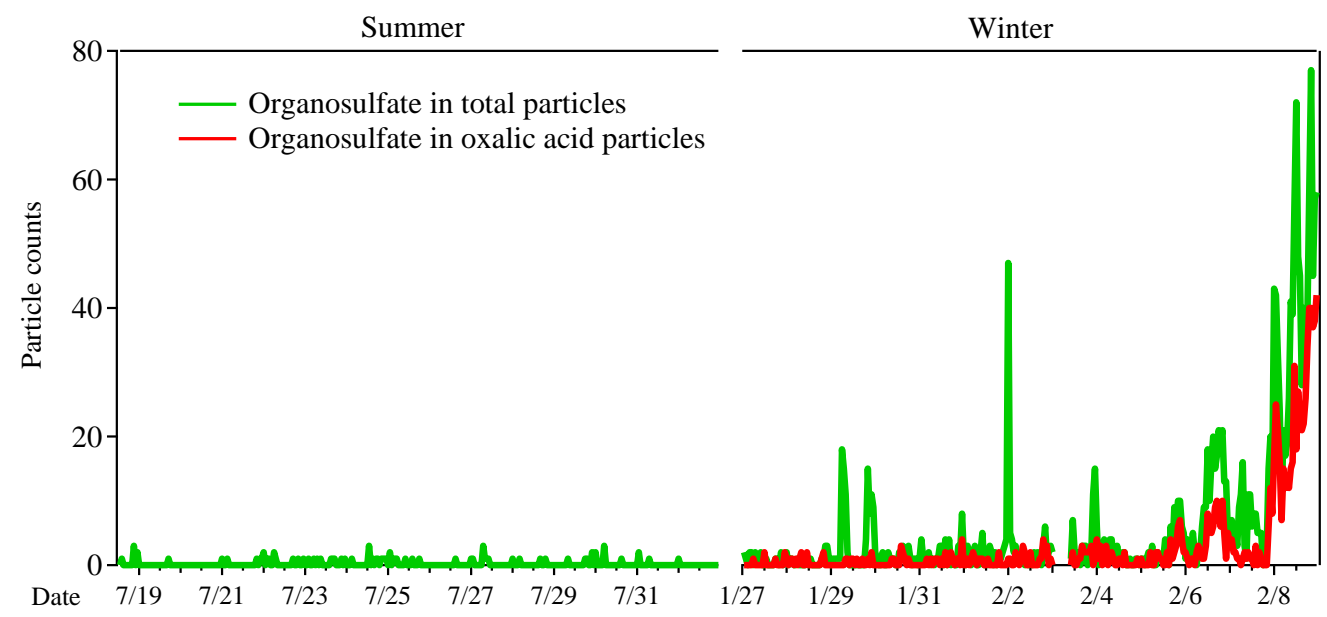

Figure S7. Temporal variation of organosulfate $(\mathrm{m} / \mathrm{z}=-155)$ containing particles in total particles and in oxalic acid particles in Heshan, China.

The organosulfate derived from reaction between glyoxal and sulfuric acid was identified at $\mathrm{m} / \mathrm{z}=-155\left(\left[\mathrm{C}_{2} \mathrm{H}_{3} \mathrm{O}_{2} \mathrm{SO}_{4}\right]^{-}\right)$based on previous work conducted by Surratt (Surratt et al., 2007;Surratt et al., 2008) and Hatch (Hatch et al., 2011) in chamber and field measurements. In current work organosulfate-containing particles were identified if the relative peak area of $\mathrm{m} / \mathrm{z}-155$ was larger than $0.5 \%$. With this threshold, 78 and 1874 of organosulfate particles were obtained in summer and winter separately, accounting for $0.01 \%$ and $0.25 \%$ in each total detected particles. The temporal trend of organosulfate-containing oxalic acid particles in winter is also shown in Figure S8, which exhibited a similar pattern as the total oxalic acid particles. The percentage of organosulfate-containing oxalic acid particles in total oxalic acid particles ranged from 0 to $16.4 \%$ with the highest ratio observed on February 8 .

\section{References}

Hatch, L. E., Creamean, J. M., Ault, A. P., Surratt, J. D., Chan, M. N., Seinfeld, J. H., Edgerton, E. S., $\mathrm{Su}, \mathrm{Y}$, and Prather, K. A.: Measurements of isoprene-derived organosulfates in ambient aerosols by aerosol time-of-flight mass spectrometry-Part 1: Single particle atmospheric observations in Atlanta, Environmental science \& technology, 45, 5105-5111, 2011.

Pathak, R. K., Louie, P. K. K., and Chan, C. K.: Characteristics of aerosol acidity in Hong kong, Atmospheric Environment, 38, 2965-2974, 10.1016/j.atmosenv.2004.02.044, 2004.

Surratt, J. D., Kroll, J. H., Kleindienst, T. E., Edney, E. O., Claeys, M., Sorooshian, A., Ng, N. L., 
Offenberg, J. H., Lewandowski, M., Jaoui, M., Flagan, R. C., and Seinfeld, J. H.: Evidence for organosulfates in secondary organic aerosol, Environmental Science \& Technology, 41, 517-527, 10.1021/Es062081q, 2007.

Surratt, J. D., Gomez-Gonzalez, Y., Chan, A. W. H., Vermeylen, R., Shahgholi, M., Kleindienst, T. E., Edney, E. O., Offenberg, J. H., Lewandowski, M., Jaoui, M., Maenhaut, W., Claeys, M., Flagan, R. C., and Seinfeld, J. H.: Organosulfate formation in biogenic secondary organic aerosol, Journal of Physical Chemistry A, 112, 8345-8378, Doi 10.1021/Jp802310p, 2008.

Xue, J., Lau, A. K. H., and Yu, J. Z.: A study of acidity on PM2.5 in Hong Kong using online ionic chemical composition measurements, Atmospheric Environment, 45, 7081-7088, 10.1016/j.atmosenv.2011.09.040, 2011.

Yao, X. H., Ling, T. Y., Fang, M., and Chan, C. K.: Comparison of thermodynamic predictions for in situ $\mathrm{pH}$ in PM2.5, Atmospheric Environment, 40, 2835-2844, 10.1016/j.atmosenv.2006.01.006, 2006. 